affections are unknown. I expressed my surprise at this information, but I do not doubt Professor Carmona's testimony, and I should be glad if he could be induced to publish his evidence, which would go far to settle this controversy.-I am, etc.,

Birmingham, Sept. 9th.

ROBERT SAUNDBY.

\section{BACTERIOLOGICAL EXAMINATION OF WATER} SUPPLIES.

Sir,-In the British Medical Jodrnal of June 9th you recommend that the water supply of Port of Spain, Trinidad, should be examined bacteriologically in addition to the usual chemical examination, and that the former mode of examination should not be confined to "a mere enumeration of the organisms present," but should extend to the number of the species, to whether they are water organisms merely, or whether they are rapidly liquefying organisms or those met with in sewage or in surface drainage, and whether they resemble pathogenic organisms or not.

I shall be greatly obliged if you will be kind enough to inform me, either through the JounNal or otherwise, of the names of the towns in the United Kingdom in which the chemical analysis is supplemented by a regular bacteriological examination of the kind you recommend and those in which the examination is confined to an enumeration of the organisms only.-I am, etc.

London, Aug. 30th.

P. Carmody.

* * As far as we are aware, there is no town, excepting London, in the United Kingdom in which any regular bacteriological examination of the water supply is made, and none at all in which the quantitative estimate of the microbes present is supplemented by a quantitative inquiry. The monthly bacteriological examination of the London water supply was commenced by Professor Percy Frankland in 1885, and was carried on by him over a period of three years for the Local Government Board. During this period a number of the different species in the water were described by Professor Frankland in a paper published in the Zeitschrift für Hygiene, 1889. The great value attaching to the bacteriological examination of a water supply like that of London depends, in our opinion, upon its controlling the efficiency of the purification (subsidence and sand filtration) to which the water is subjected. For this purpose the numerical examination is of the greatest importance, as it can be readily and frequently employed, and, if properly carried out, gives the most conclusive results. The proper determination of the various species of bacteria in a single sample of water may occupy weeks, or even months; it can therefore only be applied on special occasions, although the tests for typhoid and cholera bacilli may be made with comparative facility. Professor Carmody will find full information on these points and on the results obtained, with water supplies of different places, is given in Professor Percy Frankland's recent work, Micro-organisms in Water, published by Messrs. Longmans.

\section{NAVAL AND MILITARY MEDICAL SERVICES.}

\section{ARMY MEDICAL EXCHANGE STAFF.}

The charge for inserting notices respecting Exchanges in the Army Medical Department is ss. 6d., which should be forwarded in stamps or post office order with the notice. The first post on Thursday mornings is the latest by which these announcements can be received.

A SURGEON-LIEUTENANT-COLONEL under orders for India in November or December wishes to effect an exchange with an officer having from two to three years m
the Barracks, Athlone.

ERratum. - In the list of candidates successful at the recent examination for admission to the Army Medical Staff the name of Mr. H. E. Staddon was incorrectly printed as "Haddon."

\section{MILITIA MEDICAL STAFF CORPS}

THE officers of this corps are the regular Army Medical Staff. Medical officers have not been appointed to Militia regiments for a number of years. "M.A." can become a surgeon-lieutenant of volunteers, and
wards, as such, be transferred to the medical reserve of officers.

\section{THE NAVY.}

STAFF-SURGEON ROBERT BENTHAM is promoted to be Fleet-Surgeon, August 26 th. He was appointed Surgeon March 31st, 1874, and StaffSurgeon twelve years thereafter.

The following appointments have been made at the Admiralty: JOSEPH CrowleY, Staff-Surgeon, to the Achilles, undated; CHARLES W. BUCHANANHAMILTON, Staff Surgeon, to the Australia, September 6th; MICHAEL J. RONAN, Staff-Surgeon, to the Achilles and Nile, september 25th; EDWARD WiDEN, Staff-Surgeon, to the Scout, september 25th ; EDWARD H. GREEN, Surgeon to the Achilles, undatea ; HENRY B. HALL, Surgeon, to GREEN, Surgeon, to the Achilles, undated; HENRY B. HALL, Surgeon, to September 25th; LEONARD H. KELLETT, Staff-Surgeon, to the Hawke, September 1st.

\section{ARMY MEDICAL STAFF.}

SURgeon-Liedtenant-Colonel A. A. MACROBIN, M.B., is promoted to be Brigade-Surgeon-Lieutenant-Colonel, vice G.' R. Rae, F.R.C.S.I., deceased, August 23rd. Brigade-Surgeon-Lieutenant-Colonel Macrobin entered the service as Assistant-Surgeon March 31st, 1868, became Surgeon March 1st, 1873, Surgeon-Major March 31st, 1880, and Surgeon-LieutenantColonel March 31st, 1888. He served with the British Ambulance in the Franco German war from the time of its arrival in France in October, 1870, until its return to England in March, 1871, after the conclusion of peace, and has received the German War Steel Medal; and with the 2nd Battalion Rifle Brigade in the second phase of the Ashanti war in 1874, being present at the battles of $A$

of Coomassie (medal with clasp). Quartermaster EDWARD ENRIGHT is placed on retired pay, September
12th. He was appointed Lieutenant of Orderlies, March $7 \mathrm{th}$, 1877, and 12th. He was appointed Lieutenant of Orderlies, March 7th, 1877, and rank of Captain, May 21st, 1884 . He was in the Ashanti war in 1874 (medal); in the Eggptian war in 1882 (medal with clasp and Khedive's star); and with the soudan expedition in 1884, when he was present in the engagements at El Teb and Temai, was mentioned in despatches, promoted Honor.

Sergeant-Major JoHN BARTHoLOMEw SHORT, Medical Staff Corps, is appointed Quartermaster, with the honorary rank of Lieutenant, vice Honorary Captain E. Enright, September 12th.

The undermentioned officers, now serving in the Bombay Command, and whose tour of foreign service will expire during the trooping season of 1894-95, will proceed to England in Her Majesty's troopships, doing duty with the troops on the voyage: Surgeon-Lieutenant-Colonel H. J.

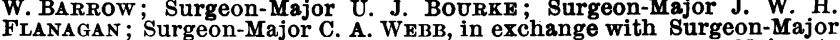
FLANAGAN; Surgeon-Major C. A. WEBB, in exchange with Surgeon-Major T. E. Noding, Bengal ; Surgeon-Major R. W. BARNES; Surgeon-Major A. PETERKIN, M.B.; Surgeon-Major J. SEMPLE; Surgeon-Captain C. R. BARTLETT, in exchange with Surgeon-Captain R. W. Nicholso
Captain R. C. THACKER ; Surgeon-Captain S. F. CLARK, M.B.

\section{THE MILITIA.}

Surgeon J. Creagh, 9th Battalion the King's Royal Rifle Corps (North Cork Militia), is promoted to be Surgeon-Captain, September 12th.

\section{CADET BATTALION.}

Mr. EDWARD ProddLove, M.B., is appointed Acting Surgeon to the 1st Cadet Batts!ion the Manchester Regiment, September 12th.

VOLUNTEER MEDICAL STAFF CORPS

SURGeON-LieUtrenaNT J. J. K. FAIRClOUGH, M.D., The Manchester Companies, is promoted to be surgeon-Captain, september 12 h.

ERratum. - In last week's issue of the BRITISH MEDICAL JournaL, Surgeon-Lieutenant Renshaw should have been described as of the Manchester Companies, and not of the London Companies.

\section{MEDICAL CHANGES IN INDIA}

THE proposals now under consideration in India are :mental administration of the Indian Medical Service in the Madras and Bombay presidencies.

2. The present Indian Surgeon-Major-General with the Governments of Madras and Bombay retain the titles and pay under existing rules.

3. The posts of secretaries to each be abolished.

4. That the Indian surgeon-major general cease to exercise any controI over reducing Indian Medical Service employed in the army or retiring of 25 per cent., administration of which would in future be directly under the orders of the Government of India.

5. All unemployed officers, of whatever rank or presidency, not filling sanctioned appointments in civil or military departments, while so unemploved, be at the disposal of the Government of India for duty in any part of India or dependencies.

6. That ultimately there be a complete unification of Indian Medical Service in all three presidencies, with the right of the Government of India to employ in any presidency.

7. Brigade-Surgeons of three presidencies to be eligible for best posts in anv presidency or province.

8. That promotion to Surgeon-General with the Government of India, and Surgeon-Major-Generals Madras and Bombay, be open to all Surgeon-Colonels of the three lists, to be selected according to seniority coupled with ability and merit; but they must complete five yeats' full pay service in these positions, including eight months' furlough, before becoming eligible for the extra pension of $£ 350$ a year. All Surgeon-
Major-Generals to be also eligible for the office of Surgeon-General with

hay, etc., rights and 9. All existing orders and regulations as to pay, etc., rights and hitherto. 